\title{
Isparta Kent Merkezinin Mekânsal Algı Değerlendirmesi
}

\author{
Elif TANRIBIR ${ }^{1 *} \odot$, Murat AKTEN ${ }^{2}$ (อ) \\ ${ }^{1}$ Süleyman Demirel Üniversitesi, Fen Bilimleri Enstitüsü, Peyzaj Mimarlığı Ana Bilim Dalı, 32260, Isparta, Türkiye. \\ 2 Süleyman Demirel Üniversitesi, Mimarlık Fakültesi, Peyzaj Mimarlığı Bölümü, 32260, Isparta, Türkiye. \\ * e-mail: eliftanribir@gmail.com \\ Öz \\ Bu çalışmanın amacı; Isparta kent merkezinin estetik durumunu peyzaj mimarlığı disiplini açısından ortaya \\ koymaktır. Çalışma mekânı olarak seçilen Isparta kent merkezi üç bölgede sınırlandırılıışıı. Araştırmada nitel \\ yöntem kullanılmış ve gözleme dayalı analiz yapılmıştır. Bu kapsamda; mekânsal değerlendirme için doğallık, \\ bakım, çeşitlilik, düzen, açıkık ve tarihi önem parametreleri kullanılmış ve değerlendirme için bir form \\ oluşturulmuştur. Toplanan bulgular doğrultusunda, formun değerlendirmesi beşli Likert yöntemi ile yapılmış ve \\ mekânsal mevcut durum tespit edilmeye çalışılmıştır. Araştırma sonucunda Isparta kent merkezinde kent \\ kimliğine uygun tasarımlara gidilemediği, Tarihi kent merkezi olması dolayısılla güçlü potansiyele sahip \\ mekânın, niteliksiz düzenlemeler ile mevcut potansiyelini yansıtamadığı görülmüş olup, Isparta kent merkezinin \\ mevcut durumu itibariyle orta düzeyde bir estetiğe sahip olduğu tespit edilmiştir.
}

Anahtar Kelimeler: Kentsel çevre, mekânsal algı, kentsel estetik, Isparta.

\section{Spatial Perception Evaluation of Isparta City Center}

\begin{abstract}
This construction purpose; Viewing Isparta outside, not the city, is to reveal the discipline of architecture. Isparta city as a working place is limited to teaching three centers. In the research, qualitative method solution and observation were analyzed. This is the scope; for spatial evaluation, a form has been created for suggesting naturalness, care, diversity, order, clarity and history. The collected findings were made with the five-point Likert method of the form and the spatial situation was tried to be determined. It has been determined that the designs suitable for being in the city center of Isparta could not be made, whether it has the potential to be in the historical city center, and that it has a medium level of aesthetics in the city of Isparta.
\end{abstract}

Keywords: Urban environment, spatial perception, urban aesthetics, Isparta.

\section{Giriş}

Günümüz kentlerinin çoğunda izlenen yapılaşma eğilimleri ve benzer yapılaşma faaliyetleri, kentlerin giderek tek tipleşmesine sebep olmaktadır. Bu süreçte kentler birbirleriyle benzerlik gösterirken, yerel özgünlüklerinin belirlediği kent kimlikleri hızla yok olma noktasına gelmektedir. Bu noktada, kimlikli ve yaşanabilir kent anlayışının ön plana çıkarılması ihtiyacı ortaya çıkmaktadır (Konuk, Olgun,

Atıf/Citation: Tanrıbir, E. ve Akten, M. (2020). Isparta Kent Merkezinin Mekânsal Algı Değerlendirmesi. Mimarlık Bilimleri ve Uygulamaları Dergisi, 5(2), 165-180.

DOI: $\underline{10.30785 / \mathrm{mbud} .695520}$ 
Öğdül, Ergönül, Seçkin, Başık, Manco, 2017). Bu ihtiyacı gidermek amacıyla, kentsel tasarımlar dâhilinde yapılan uygulamaların bütüncül, kullanıcısına hizmet eden, algısal ölçütlerin değerlendirildiği, kent yapısına uygun ve nitelikli olması gerekmektedir. Böylece toplumsal duyarlılık dikkate alınarak gerçekleştirilen mekânsal değişimler, değişimin yaşandığı kentin kimliğini güçlendirecektir (Tekel ve Arı, 2013). Kentlerdeki kamusal alanların estetik değeri mekânsal kaliteyi oluştururken insanların da yaşam kalitesini etkilemektedir. Mekânsal değerlendirmeler yapılarak kentsel estetik potansiyelin ölçülmesi ile daha okunabilir, işlevsel, kaliteli, nitelikli kentsel mekânlar tasarlamak mümkündür. Kentsel tasarım sürecinde yapılabilecek bu değerlendirmeler tasarlanan mekânların kent kültürüne ve doğasına daha uygun, sürdürülebilir, kimlikli kentler haline gelmesine katkı sağlayacaktır. Böylece kentler her açıdan değer kazanacak ve kullanıcılarının yaşam kalitesini arttırmış olacaktır. "Kentsel tasarım; yaşanabilir, sağlıklı, kaliteli, erişilebilir ve kullanılabilir mekânlar (kent semt-mahalle-sokak-bina ve obje) ölçeğinde bütüncül, sürdürülebilir koruma ve geliştirmeye yönelik organize etme, düzenleme ve uygulamayı içeren eylemsel bir süreç ve disiplinler arası bir yaklaşımdır" (Gül ve Bostan, 2018).

Kamusal alanların etkili bir şekilde tasarlanması ve yönetilmesi için, kentsel mekânların insanların yaşamlarında oynadığı rolü ve mekânların neden kullanıldı̆ııı veya göz ardı edildiğini anlamak önemlidir. İnsan çevre ilişkisindeki estetik yargılar, kentsel tasarım kriterleri için sağlam bir zemin oluşturur ve kentsel tasarımda önemli bir araştırma konusudur. Bu bağlamda algı kriterleri ile beğeni düzeyi arasındaki ilişkiyi kavramak ve kamusal alanlardaki beğenileri sağlayan estetik değişkenleri irdelemek gerekmektedir. Kentsel mekânlardaki estetik değerleri incelemek, ne tür fiziksel özelliklerin mekânları estetik hale getirdiğini bulmayı sağlayacaktır (Tekel, Ceylan Kızıltaş ve Afshar, 2018). Kentsel mekân; bir toplumun geleneksel kültürel zenginliği ve çağın getirilerinin harmanlandığı yaşam alanı, kentsel estetik ise bu harmanın algılanışı sonucunda oluşan bir olgudur. Insan ve çevre arasındaki etkileşim algı yolu ile olur. Algı, çevre hakkında bilgi toplama, değerlendirme ve anlamlandırma şeklinde gerçekleşmektedir. Bu süreçte bireyin deneyimleri, sosyal ve kültürel yapısı da algı üzerinde etki sahibidir. Kentsel mekânlar, kullanıcısı ile etkileşim halinde bir bütündür. Kentsel mekânlardaki elemanların tasarımı ve organizasyon ilkeleri, mekânsal algı ve imgeyi etkilemektedir (Lynch, 1979). Mekânsal algılamanın temelinde, insan-çevre etkileşimi yatmakta ve fiziksel mekânın karmaşık düzenini algılama, kavrama ve kaydetme süreci, mekânsal elemanlar ve organizasyon ilkelerinden etkilenmektedir. Mekânsal elemanların, biçim, renk ve boyut gibi belirgin nitelikleri ve çevredeki diğer elemanlardan farklılaşması ve zıtlık oluşturması, aynı zamanda birey için anlam ifade etmesi, algı ve belleğin çalışmasını etkilemektedir. Birey çevresel uyarıcıları zihninde ilişkilendirerek yorumlamaktadır. Mekânsal algıyı önemli düzeyde etkileyen organizasyon ilkelerinin literatürde yapılan çalışmalarca; düzen, uyum, insan ölçeği, çeşitlilik, kapalılık ve süreklilik olduğu belirtilmektedir (Akbarishahabi, 2017). Ayrıca bunların yanında doğallık, bakım ve tarihi önemde mekânsal algı için önem arz etmektedir (Nasar, 1992). Düzen, okunaklı bir mekânın altyapısını oluşturan önemli bir kavramdır. Düzen, insanlara mekânı kolayca tanıma, deneyimleme, hareket etme ve kolayca yön bulma olanağı sağlamaktadır. Kentsel mekânda, binalar, kentsel donatılar ve doğal elemanların dizilimi ne çok monoton ne de çok karmaşık olmalıdır. Düzenli, fazla çeşitlilik kullanıcılara mekânların daha algılanabilir olmasını sağlamaktadır (Maddox, 1990).

Kentlerde tek düze yapılardan oluşan, birbirine benzer elemanların yer aldığı, mekânsal düzenleme elemanlarının arasındaki kurgu zayıf, niteliksiz ve okunaklıığı düşük mekânlar kolay algılanamamaktadır. Bu mekânların monotonluğu çeşitlilik algısını düşürmektedir. Ayrıca bu gibi durumlar kent kimliğini de olumsuz etkilemektedir (Alexander, Ishikawa ve Silverstein, 1977). Uyumlu çevreler düzen içerir ve uyumlu bir çeşitlilik de mekânın bütün olarak algılanmasını kolaylaştırarak, hatırlanmasını etkilemektedir. Mekânsal tercihlerde kullanıcı orta seviyede çeşitli ve yüksek seviyede uyumlu, bakımlı, tarihi öneme sahip, doğal eleman varlığı yüksek olan ortamları seçmektedir. Uyum ve çeşitlilik bir mekânda bir arada olmalıdır. Çeşitliliği olmayan uyumlu ortamlar, insanlar için monoton ve sıkıcı olabilmektedir. İnsanlar için genel algı; yüksek uyum düşük çeşitlilik, sıkıcı algılanırken düşük uyum yüksek çeşitlilik, dağınık ve yüksek uyum yüksek çeşitlilik de ihtişam ve düzen algısı yaratmaktadır (Kaplan ve Kaplan, 1989). 
Mekânsal algıyı etkileyen bir diğer unsur da mekânın kapalııı durumudur. Kapalııı, kentsel mekânlardaki yapılar, ağaçlar ve mekânda konumlandırılan diğer düşey elemanlar tarafından algısal olarak sınırlama ve tanımlamadır. Kapalıık derecesi, düşey elemanların yüksekliği ile yatayda bulunan elemanlar arasındaki genişlik oranı olarak ifade edilmektedir (Ewing, Handy, Brownson, Clemente ve Winston, 2006). Mekânsal algıda kapalıık derecesinin kullanıcılar tarafından iyi algılanabilmesi için sokak genişliğinin sokağı çevreleyen bina yüksekliklerinden fazla olmaması gerekmektedir (Alexander, Ishikawa ve Silverstein, 1977). Kapalılığın yanı sıra kentsel mekân olgularının insan ölçeğinde olması da algıyı etkileyen bir diğer unsurdur. Kentsel mekânlarda sokak genişliği, bina yükseklikleri vb. gibi unsurlar insan ölçeğini etkilemektedir. Kentsel mekanlarda bulunan her türlü yapı, donatı elemanları, peyzaj ögeleri vb. gibi mekânı oluşturan her elemanın boyutu, dokusu, rengi insan ölçeği algısını etkilemektedir (Ewing vd., 2006). Kısaca kentsel mekânlarda yer alan açık ve yeşil alanlar, yollar, binalar, peyzaj ögeleri, kentsel donatı elemanları bir bütünün parçalarını oluşturur ve kentsel mekân ile ilgili bilgi vererek kullanıcı algısını etkilemektedir. Mekânsal değerlendirmelerde insan mekân arasındaki ilişkiyi anlamak adına; şehir planlama, mimar, coğrafya, peyzaj mimarlığı vb. gibi pek çok disiplinin algı ölçütlerini araştırdığı görülmektedir. Algı ölçütleri kentsel mekânlara verilen estetik tepkiyi ve bunun sonucu olarak insanlar için günlük şehir sokaklarında yaşadıkları deneyim memnuniyetini büyük ölçüde etkilemektedir (Tekel, Ceylan Kızıltaş, ve Afshar, 2018). Açık ve yeşil alanlara kullanıcılar tarafından anlam ve olumlu değerler yüklenmesi, kentteki bu alanların değerini arttırabilmektedir (Ender Altay ve Pirselimoğlu Batman, 2019).Kentsel mekânlarda kullanıcı ihtiyaçlarının karşılanması noktasında peyzaj donatılarının ne düzeyde yeterli olduğu, kullanım sırasında mekânların kişilere hangi derecede yanıt verebildiği, sert-zemin yeşil alan dengesinin nasıl kurulduğu, uygulamaların mekân dokusuna ne kadar uyum sağladığı, mekânların kullanıcısı tarafından nasıl algılandığı vb. gibi durumlar çevresel konforun sağlanabilmesi adına sorgulanması gereken durumlardır. Mekânsal algıları anlamak alana özgü nitelikli planlama ve tasarımlar yapılmasına katkı sağlayacaktır.

Bu doğrultuda bu çalışma mekân algısının değerlendirilmesiyle daha verimli kentsel mekânlar tasarlana bilineceği hipotezini öne sürmektedir. Bu amaçla bu çalışmada Isparta kent merkezinin mekânsal kurgusu ve estetik durumu peyzaj mimarlığı disiplini açısından irdelenmeye çalışılmıştır. Insan mekân etkileşimindeki algıları anlamak daha fonksiyonel ve bütüncül tasarımların ortaya konmasına katkı sağlayacaktır.

\section{Materyal ve Yöntem}

\subsection{Materyal}

Çalışma alanı olarak seçilen alan, Isparta'nın kent merkezidir. Isparta ili Türkiye'nin güneyinde, Akdeniz Bölgesi'nin batısında yer almaktadır (Şekil 1).

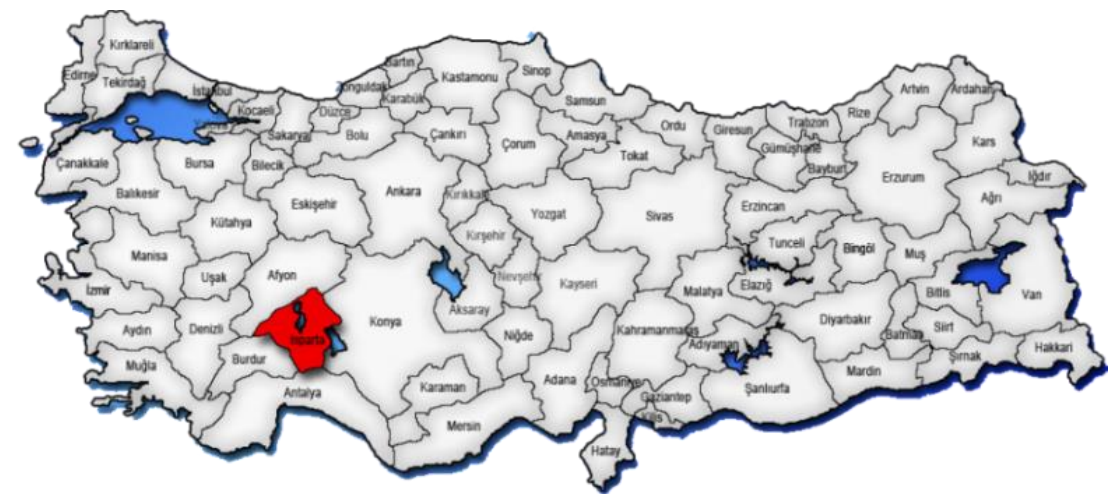

Şekil 1. Isparta'nın Türkiye içindeki konumu (Lafsozluk, 2018)

Isparta ilinin kuzeyinde Afyonkarahisar, doğusunda Konya, güneyinde Antalya ve güneybatısında da Burdur illeriyle komşu konumundadır. Ayrıca Isparta ili matematiksel konum olarak $37^{\circ} 21^{\prime}$ ve $38^{\circ} 30^{\prime}$ kuzey enlemleriyle, $30^{\circ} 04^{\prime}$ ve $31^{\circ} 32^{\prime}$ doğu boylamları arasında yer almaktadır. Isparta ilinin 2019 yılına ait nüfusu, tahmini verilere göre $442.616^{\prime}$ dir. $8.933 \mathrm{~km} 2^{\prime} l i k$ yüzölçümüne sahip olan şehrin rakımı ortalama 1050 metredir. Isparta kent merkezi güneyden kuzeye doğru az eğimli bir 
topoğrafyaya sahip olup, güneyi yüksek dağlarla çevrilidir. Isparta, Akdeniz iklimi ile Orta Anadolu'da yaşanan karasal iklim arasında geçiş bölgesinde yer alması nedeniyle, bölgede her iki iklimin özellikleri de gözlenmektedir (Türkiye Cumhuriyeti Isparta Valiliği, 2018).

Isparta kent merkezini konu alan bu çalışmanın alan seçiminde alanın tarihi kent merkezi niteliği taşıması, içerisinde sivil mimari özelliğe sahip yapıların bulunması ve bu yapıların her birinin kentin birer imgesi haline gelmiş tanınırlıkta yapılar olması önem arz etmektedir. Kentleşmenin başladığı andan itibaren ilk kentsel yerleşme ve yapılaşmanın gerçekleştiği alan olması sebebiyle de kentin kimliğine dair bilgileri içermektedir. Aynı zamanda Kentsel Sit ve Tarihi Sit Alanı olarak ilan edilmesi, tarihi ve kültürel özellikleriyle görsel peyzaj değerlendirmesi açısından güçlü veriler barındırması alanın seçilmesinde etkili olmuştur.

Çalışmanın alan sınırları imar planı üzerinde Şekil 2'de gösterilmektedir. Haritada da görüldüğü gibi çalışma alanının sınırları, alanın güneybatısındaki Cumhuriyet Caddesi ve Hastane Caddesi'nin kesiştiği caddeden başlayarak, alanın kuzey-doğusundaki Doğan Kımılı Caddesi'nin İstasyon Caddesi'ni kestiği cadde arasında kalan bölgeyi kapsamaktadır. Hazırlanan bu plan üzerinde; çalışma alan sınırları, Kentsel Sit Alan sınırları, tescilli anıtsal yapılar, yollar, düğüm noktaları, park ve yeşil alanlar, resmi kurumlar, plastik objeler, askeri alan, eğitim alanı, dini tesisler, ticari ve konut alanları gösterilmektedir. Ayrıca çalışma alan sınırı içerisinde üç mahallenin bazı sokak ve caddeleri kısmen yer almaktadır. Bunlar; Kutlu Bey, Çelebiler ve Piri Mehmet Mahalleleridir.

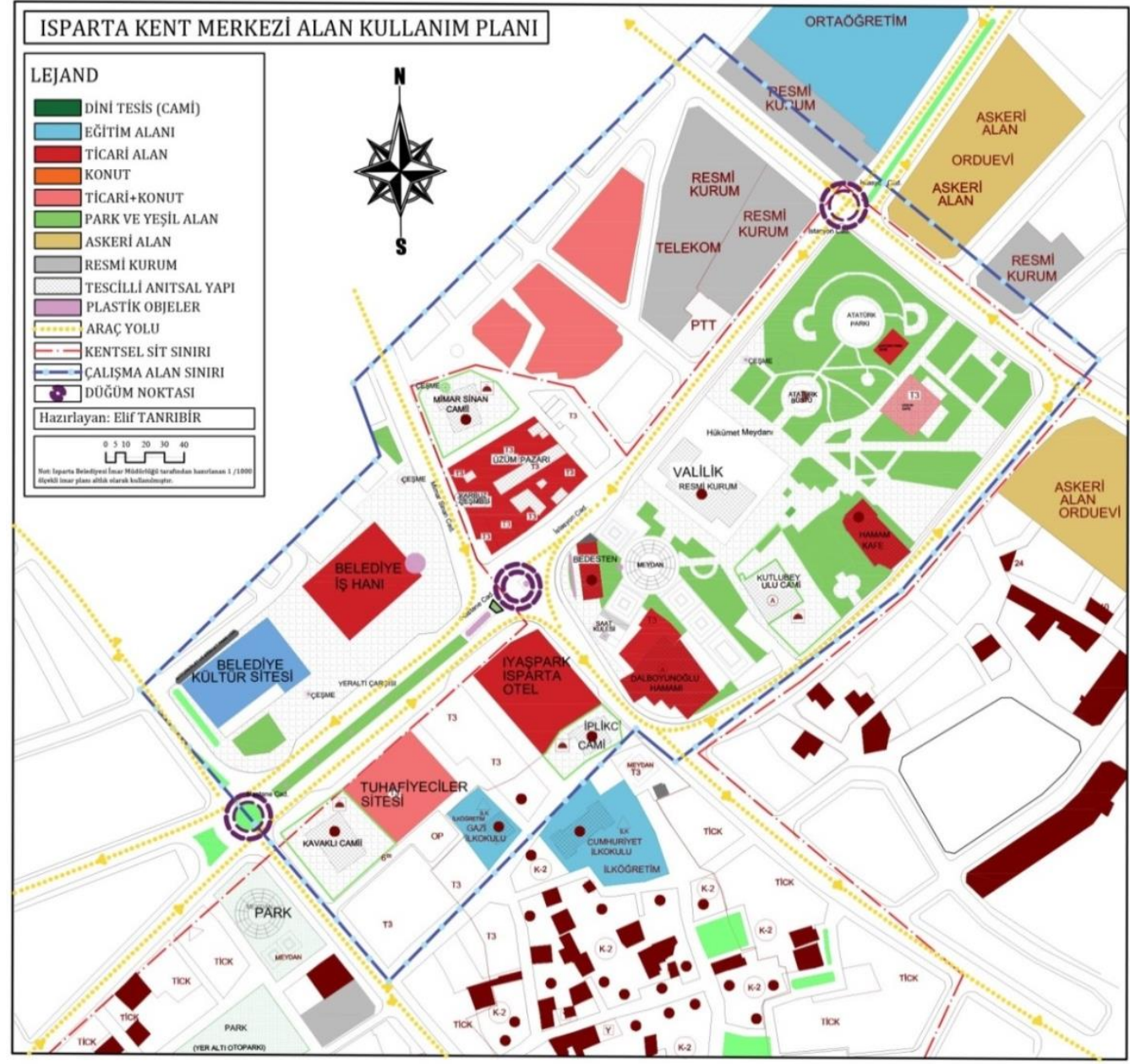

Şekil 2. Isparta kent merkezi alan kullanım planı

\subsection{Yöntem}

Bu çalışmanın değerlendirilmesinde nitel yöntem kullanılmıştır. Veri toplama aracı olarak ise gözlem seçilmiştir. Nitel gözlem sayısal veri üretmekten çok, araştırmaya konu olan olay, olgu ve duruma ilişkin derinlemesine tanımlamalar yapmadır. Gözlem ise belli bir kimse, yer, olay, nesne, durum ve şarta ait bilgi toplamak için belirli hedeflere yöneltilmiş bir bakış ve dinleyiştir. Gözlemin araştırmaya 
katkılarından biri doğrudan doğruya olayın görgü tanığından (araştırmacıdan), kaynağından elde edilen kanıtların resmedilmesi bir diğeri ise bahsedildiği gibi ayrıntılı açıklama ve tanımlamalar yapma imkânı sunmasıdır (Sözbilir, 2011). Bu bağlamda bu çalışma dört aşamadan oluşmaktadır.

I. Çalışmanın ilk aşamasında araştırmaya kuramsal anlamda zemin hazırlayacak kavramlar irdelenmiştir. Literatür taraması verilerini; doktora ve yüksek lisans tezleri, makaleler, internet kaynakları, bildiriler, kitap ve dergiler vb. kaynaklar oluşturmaktadır. Konu ile ilgili yerli ve yabancı kaynakların yer aldığı literatür taramaları yapılmış ve uluslararası kaynaklardan elde edilen örnekler değerlendirilmiştir.

II. Araştırmanın ikinci aşamasında, Isparta kent merkezi mevcut kamusal dış alanlarını irdelemek amacıyla Isparta Belediyesi'nden 1/1000 ölçekli imar planı temin edilmiş ve alan sınırları belirlenerek, alan hakkında ilgili kurum ve kuruluşlardan veriler toplanmıştır.

III. Araştırmanın üçüncü aşamasında veri toplama, analiz, sentez, değerlendirme işlemleri için farklı zamanlarda alana gidilerek, yerinde yapılan gözlem ve incelemeler ile 300 fotoğraf çekilmiştir.

IV. Araştırmanın dördüncü aşamasında alan hakkında elde edilen bilgiler Nasar (1992)'ın "Visual preferences in urban street scenes: a cross cultural comparison between Japan and the United States" isimli çalışmasında kullandığı çevresel değerlendirme parametreleri temel alınarak, Akbarıshahabı (2017)'ın "İmgelenebilir Kentsel Mekânların Niteliklerinin Fraktal Yaklaşım ile Saptanması ve Bir Tasarım Gramerinin Geliştirilmesi" adlı doktora tezinde yer alan, mekânsal algıyı etkileyen fiziksel nitelikler tablosu yardımı ile parametreler geliştirilmiş ve görsel değerlendirme için bir form oluşturulmuştur.

Bu bağlamda alanın kentsel estetik düzeyi değerlendirilirken altı ölçüt kullanılmıştır. Bunlar: Doğallık, açıklık, bakımlıık, düzen, çeşitlilik ve tarihsel önem şeklinde sıralanmaktadır. Değerlendirme yapılırken alanın: Doğallığı (Doğal eleman varlığının azlık-çokluk derecesi), Düzenli mi yoksa Kaotik mi olduğu, Bakımlı- Bakımsız olduğu, Açıklık - Kapalılık özelliği gösterdiği, Basit ya da Çeşitli olduğu, Tarihsel Öneme sahip olup olmadığı göz önünde bulundurularak çalışma gerçekleştirilmiştir. Hazırlanan formun puanlamasında 5'li Likert'den yararlanılmıştır. Tablo değerlendirilmesi -2 ve +2 (-2: çok kötü, -1: kötü, 0: orta, 1: iyi, 2: çok iyi) arasında puanlar verilerek oluşturulmuştur (Şekil 3).

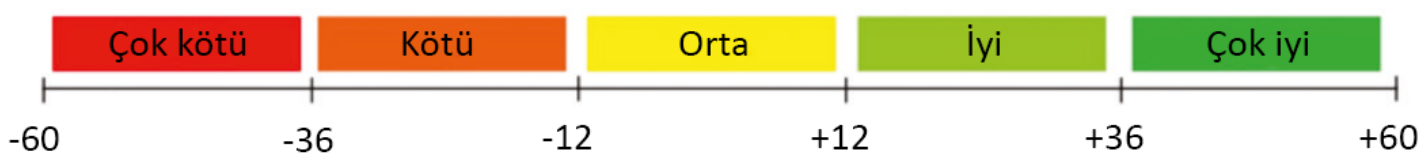

Şekil 3. Mekânsal algı düzeyini belirlemede kullanılan değer aralıkları çizelgesi

Oluşturulan Şekil 3 ile çalışma alanının görsel peyzaj değerlendirilmesi yapılmaya çalışılmıştır. Bu kapsamda alan önce üç bölgeye ayrılmış ve her biri kendi içinde ayrı ayrı değerlendirilmiştir. Akabinde bölgelerin toplam puanları incelenerek alan bütünü hakkında sonuçlar ortaya konmuştur. Sonuçlar doğrultusunda Isparta kent merkezi kentsel tasarımının kullanıcı ihtiyaçlarını karşılama noktasında ne düzeyde yeterli olduğu, kentsel ögeleri kullanım sırasında fonksiyonel olarak kişilere ne derece yanıt verebildiği, kent estetiği ve mekânsal konforun sağlanabilmesi adına sorgulanması gereken durumların değerlendirilmesi yapılmıştır. Değerlendirme sonuçları peyzaj mimarlığı disiplini açısından irdelenmeye çalışımış ve ısparta kent merkezi için çeşitli öneriler geliştirilmiştir. Gözlem bulgularının değerlendirilmesi için hazırlanan form Çizelge 1'de gösterilmektedir. 
Çizelge 1. Bölgesel değerlendirme formu

\begin{tabular}{|c|c|c|c|c|c|}
\hline \multicolumn{2}{|c|}{ Bölgesel Değerlendirme Formu } & \multicolumn{3}{|c|}{ Bölgeler } & \multirow{2}{*}{$\begin{array}{c}\text { Toplam } \\
\text { Puan }\end{array}$} \\
\hline \multicolumn{2}{|c|}{ Kriterler } & I. & & III. & \\
\hline 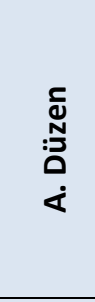 & $\begin{array}{l}\text { Bina yüksekliklerinin uyumu } \\
\text { Bina cephelerinin benzer hizada olması } \\
\text { Donatı elemanlarının birbirleriyle uyumu } \\
\text { Peyzaj ögelerinin uyumu (Ağaçlar, çalılar, yer örtücü vb.) } \\
\text { Bina cephesindeki detaylar ve eklemelerin insan ölçeğinde olması } \\
\text { Donatı elemanlarının insan ölçeğinde olması } \\
\text { Sokak genişliğinin insan ölçeğinde (düşük) olması }\end{array}$ & & & & \\
\hline $\begin{array}{l}\text { 兰 } \\
\substack{\bar{c} \\
\infty}\end{array}$ & $\begin{array}{l}\text { Sokağın iki tarafını kuşatan binaların } 4 \text { kattan fazla olmaması } \\
\text { Kapalılık oranı (Bina yüksekliğinin sokak genişliğine olan oranı) } \\
\text { Bina cephelerindeki ritim, tekrar ve benzerlik } \\
\text { Peyzaj ögelerinin yoğunluğu } \\
\text { Donatı elemanlarının yoğunluğu }\end{array}$ & & & & \\
\hline 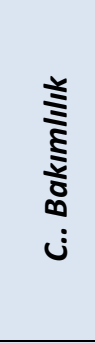 & $\begin{array}{l}\text { Bina cepheleri } \\
\text { Yer döşemeleri } \\
\text { Oturma elemanları } \\
\text { Aydınlatma elemanları } \\
\text { Heykeller } \\
\text { Peyzaj ögeleri (Ağaçlar, çalılar, yer örtücü vb.) } \\
\text { Çöp kutuları } \\
\text { Çeşmeler }\end{array}$ & & & & \\
\hline 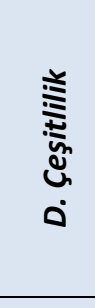 & $\begin{array}{l}\text { Farkı yükseklikteki binalar } \\
\text { Farklı cephe düzenlemeleri } \\
\text { Donatı elemanları (Çeşmeler, aydınlatma elemanı, } \\
\text { Oturma elemanları, heykeller, yer döşemeleri vb.) } \\
\text { Otopark (Kapalı otopark, Bisiklet, Motosiklet park yeri) } \\
\text { Renk, doku ve malzeme çeşitliliği } \\
\text { Peyzaj ögeleri (Ağaçlar, çalılar, yer örtücü vb.) }\end{array}$ & & & & \\
\hline 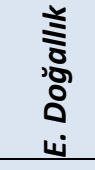 & $\begin{array}{l}\text { Doğal eleman varlığının yoğunluğu } \\
\text { Donatı elemanlarındaki doğal malzeme kullanımı }\end{array}$ & & & & \\
\hline Li: & $\begin{array}{l}\text { Kentsel Sit Alan varlığı } \\
\text { Anıtsal yapı varlığı }\end{array}$ & & & & \\
\hline & Toplam & & & & \\
\hline
\end{tabular}

\section{Bulgular ve Tartışma}

\subsection{Arazi gözlem bulguları}

Çalışma alanının daha iyi analiz edilebilmesi ve büyük bir alana sahip olması sebebiyle alan üç bölgeye ayrılmıştır. Çalışma alanının bölgelerini gösteren harita Şekil 4'de görülmektedir. Elde edilen veriler üç aşamada sunulmaktadır. illk adımda bölgeler hakkında genel bilgiler verilmiş; sonrasında ise bulgular, mekânsal analiz için hazırlanan formun değerlendirmesine yönelik çizelgeler halinde sunulmuştur. Üçüncü ve son aşamada ise bölgelere ait bazı donatı elemanlarının fotoğrafları yer almaktadır. 


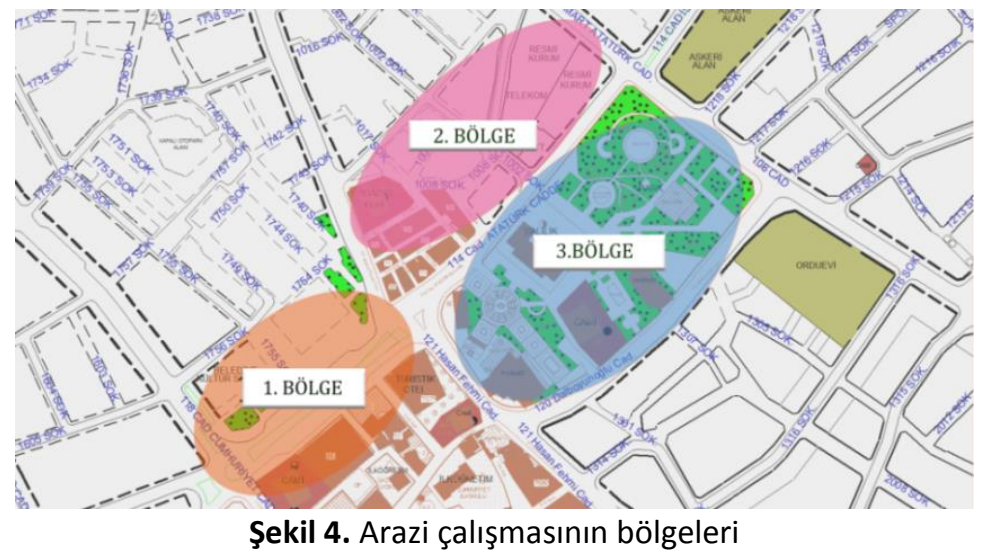

\subsubsection{Birinci bölgeye genel bakış}

Kent kullanıcıları için bu alan sıklıkla bir toplanma, dağılma ve bekleme noktası şeklinde kullanılan, büyük oranda alışveriş imkânı sunan, yol akslarının merkezcil sistemiyle birlikte bir geçiş güzergâhı olarak kullanımı artan bir alan olarak tanımlamak mümkündür. Bu bölge sınırları içerisinde 1 anıtsal yapı (Kavaklı Cami), park, iş hanı, Tuhafiyeciler Sitesi, otel, yeraltı çarşısı, alışveriş imkânı sunan çeşitli dükkânlar (eczacı, fotoğrafçı, fırın, market, mağaza vb.), yemek yeme imkânı sunan; dönerciler, kebapçı, kafeterya gibi birçok intiyacı karşılayacak çeşitli mekânlar bulunmaktadır (Şekil 5).
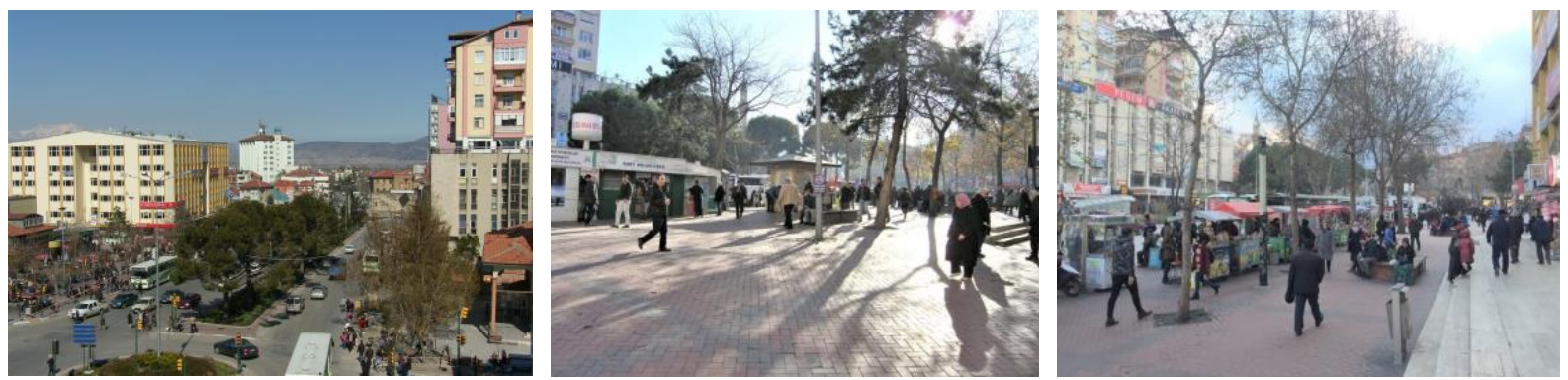

Şekil 5. I. Bölgeden genel görünüşler

\subsection{2. İkinci bölgeye genel bakış}

Alan içerisinde Mimar Sinan Cami, Tarihi Üzüm Pazarı, konutlar, ticari yapılar, adliye, oteller vb. gibi kullanımlar yer almaktadır. Bu bölgede beş sokak ve bir cadde yer almaktadır. Bir kısmı da yayalaştırımış durumdadır. Gerekli durumlar dışında araç giriş çıkışı yapılmamaktadır. Tarihi Üzüm Pazarı ve Mimar Sinan Cami'nin bulunduğu alan Antalya Kültür ve Tabiat Varlıklarını Koruma Kurulu'nun 26.07.1992 tarihli ve 1495 sayılı kararı ile Kentsel Sit Alanı olarak ilan edilmiştir. Üzüm Çarşı'sı içerisindeki 16. yüzyıla tarihlenen 16 adet dükkân tescillenmiştir. Alandaki en eski tarihli yapı olan Mimar Sinan Cami ise 10.02.2005 tarihli ve 241 sayılı karar ile tescil altına alınmıştır. Bu yapıların varlığı alanın tarihi dokusunu güçlendirmektedir. Bu bölgeye ait birkaç fotoğraf Şekil 6'da yer almaktadır.
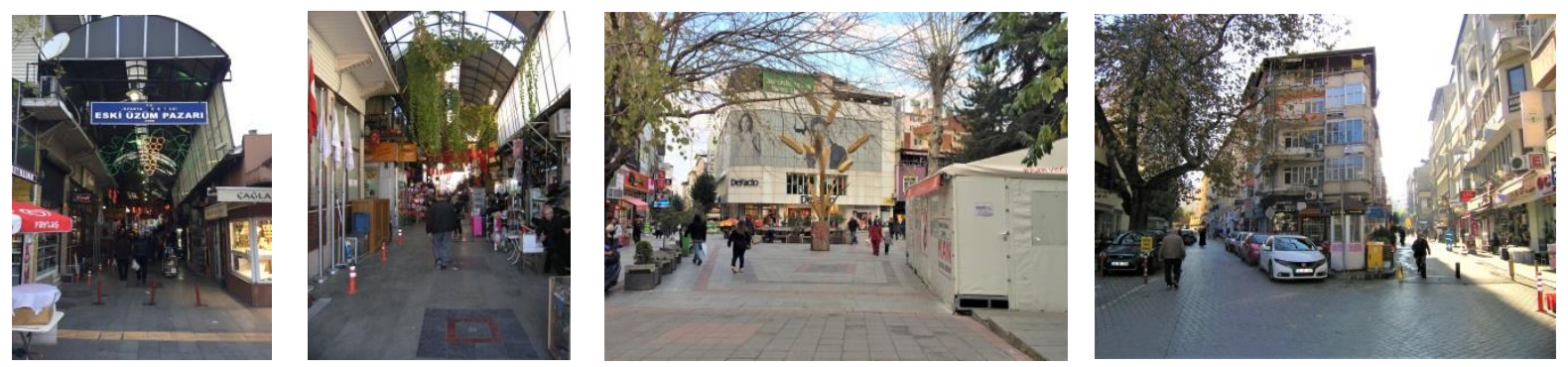

Şekil 6. II. Bölgeden genel görünüşler

\subsection{3. Üçüncü bölgeye genel bakış}

Üçüncü alan olarak seçilen bölge bütünüyle Kentsel Sit Alanı sınırları içerisinde yer almaktadır. Alanda toplamda beş adet anıtsal yapı bulunmaktadır. Tarihi kent merkezindeki resmi ve ticari yapılar olan Valilik Bina'sı, Dalboyunoğlu Hamamı, Bey Hamamı, Firdevsbey Bedesteni ve Kutlubey Ulu Cami'nin 
bir arada bulunduğu alan Antalya Kültür ve Tabiat Varlıklarını Koruma Kurulu'nca Tarihi Sit Alanı olarak ilan edilmiştir. Alanın yaklaşık yarısında yeşil alan mevcuttur. Şekil 7 'de bu bölgeye ait mekânların bulunduğu fotoğraflar yer almaktadır.
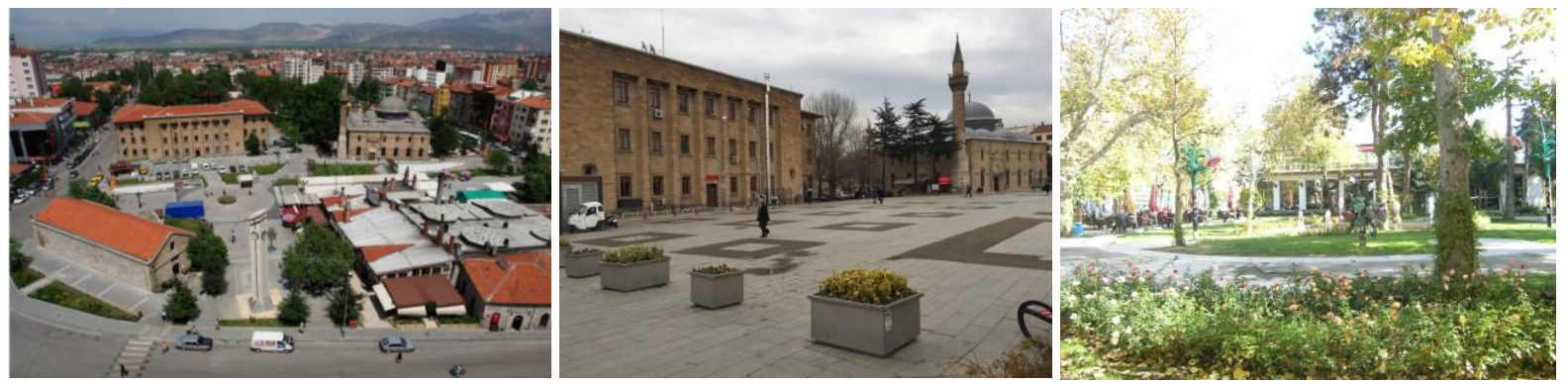

Şekil 7. III. Bölgeden genel görünüşler

Yapılan analizler doğrultusunda, alan değerlendirilmesi için hazırlanan form tüm bölgeler için ayrı ayrı puanlanmıştır. Puanlama bulguları kriterlere göre tablo halinde verilmiştir. Üç bölgeye ait doğallık, tarihi önem, düzen, açıklık, bakım ve çeşitlilik parametreleriyle ilgili bulgular çizelge 2 ve 3'de tablo halinde verilmiştir.

Çizelge 2. Mekânsal değerlendirmeye yönelik düzen ve açıklık parametre bulguları

\begin{tabular}{|c|c|c|c|}
\hline \multicolumn{4}{|c|}{ BÖLGELER } \\
\hline & I. & II. & III. \\
\hline 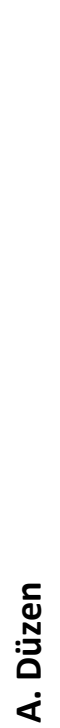 & $\begin{array}{l}\text { - Bina yükseklikleri uyumsuzdur. } \\
\text { - Bina cepheleri kısmen benzer } \\
\text { hizada konumlandırılmıştır. } \\
\text { - Donatı elemanları birbirleriyle } \\
\text { uyumsuzdur. } \\
\text { - Peyzaj ögeleri (Ağaçlar, çalılar, } \\
\text { yer örtücü vb.) kısmen } \\
\text { uyumludur. } \\
\text { - Bina cephesindeki detaylar ve } \\
\text { eklemelerde insan ölçeğinde } \\
\text { olmayan yerler mevcuttur. } \\
\text { - Donatı elemanlarında yer yer } \\
\text { insan ölçeğine uymayan } \\
\text { örnekler vardır. (gül heykeli, gül } \\
\text { formundaki lambalar vb.) } \\
\text { - Sokak genişliği bölgenin } \\
\text { yarısında insan ölçeğinde } \\
\text { değildir. }\end{array}$ & $\begin{array}{l}\text { - Bina yükseklikleri genel } \\
\text { itibariyle uyumludur. } \\
\text { - Bina cepheleri benzer hizadadır. } \\
\text { - Donatı elemanları birbirleriyle } \\
\text { kısmen uyumludur. } \\
\text { - Peyzaj ögeleri (Ağaçlar, çalılar, } \\
\text { yer örtücü vb.) kısmen } \\
\text { uyumludur. } \\
\text { - Bina cephesindeki detaylar ve } \\
\text { eklemelerde insan ölçeğinde } \\
\text { olmayan yerler mevcuttur. } \\
\text { - Donatı elemanlarında yer yer } \\
\text { insan ölçeğine } \\
\text { örnekler vardır. (başak heykeli, } \\
\text { süs havuzu, gül formundaki } \\
\text { lambalar vb.) } \\
\text { - Sokak genişliği } \\
\text { ölçeğindedir. }\end{array}$ & $\begin{array}{l}\text { - Bina yükseklikleri uyumludur. } \\
\text { - Bina cepheleri kısmen benzer } \\
\text { hizadadır. } \\
\text { - Donatı elemanları birbirleriyle } \\
\text { uyumsuzdur. } \\
\text { - Peyzaj ögeleri (Ağaçlar, çalılar, } \\
\text { yer örtücü vb.) uyumludur. } \\
\text { - Bina cephelerindeki detaylar } \\
\text { eklemeler insan ölçeğindedir. } \\
\text { - Donatı elemanları insan } \\
\text { ölçeğindedir } \\
\text { - Sokak genişliği bölgenin } \\
\text { yarısında insan ölçeğindedir. }\end{array}$ \\
\hline 美 & $\begin{array}{l}\text { - Sokağın iki tarafını kuşatan } \\
\text { binaların yüksekliği simetri } \\
\text { oluşturmamakta ve bir sıra } \\
\text { dizilim göstermemektedir. } \\
\text { - Sokağın genişliği } 15+8 \text { metre } \\
\text { şeklinde olup bölünmüş yoldur. } \\
\text { - Bina cephelerindeki ritim, tekrar } \\
\text { ve benzerlik azdır. } \\
\text { - Peyzaj ögeleri (ağaç boyları) } \\
\text { refüjün bir bölümündeki } \\
\text { yıllanmış ağaçlar dışında } \\
\text { kapalılık hissi yaratmamaktadır. } \\
\text { - Donatı elemanları alanın } \\
\text { yarısında daha yoğun } \\
\text { kullanılmıştır. }\end{array}$ & $\begin{array}{l}\text { - Sokağın iki tarafını kuşatan } \\
\text { binaların yüksekliği simetri } \\
\text { oluşturmakta ve bir sıra dizilim } \\
\text { göstermektedir. } \\
\text { - Sokağın genişliği } 7 \text { ile } 10 \text { metre } \\
\text { arasında değişiklik } \\
\text { göstermektedir. } \\
\text { - Bina cephelerindeki ritim, } \\
\text { tekrar ve benzerlik fazladır. } \\
\text { - Peyzaj ögeleri, az sayıda } \\
\text { olmaları sebebiyle kapalılık hissi } \\
\text { yaratmamaktadır. } \\
\text { - Donatı elemanları bu bölge } \\
\text { genelinde az kullanılmıştır. }\end{array}$ & $\begin{array}{l}\text { - Sokağın iki tarafını kuşatan } \\
\text { binaların yüksekliği simetri } \\
\text { oluşturmamakta ve bir sıra } \\
\text { dizilim göstermemektedir. } \\
\text { - Sokağın genişliği bölge } \\
\text { çevresinde 10-15 metre şeklinde } \\
\text { olup bölünmüş yoldur. } \\
\text { - Bina cephelerindeki ritim, tekrar } \\
\text { ve benzerlik fazladır. } \\
\text { - Peyzaj ögeleri bu bölgenin bir } \\
\text { bölümünde yoğun kullanıma } \\
\text { sahiptir. } \\
\text { - Donatı elemanları alanda genel } \\
\text { olarak eşit } \\
\text { göstermektedir. dağılım }\end{array}$ \\
\hline
\end{tabular}


Çizelge 3. Mekânsal değerlendirmeye yönelik bakım, çeşitlilik, doğallık ve tarihi önem parametre bulguları

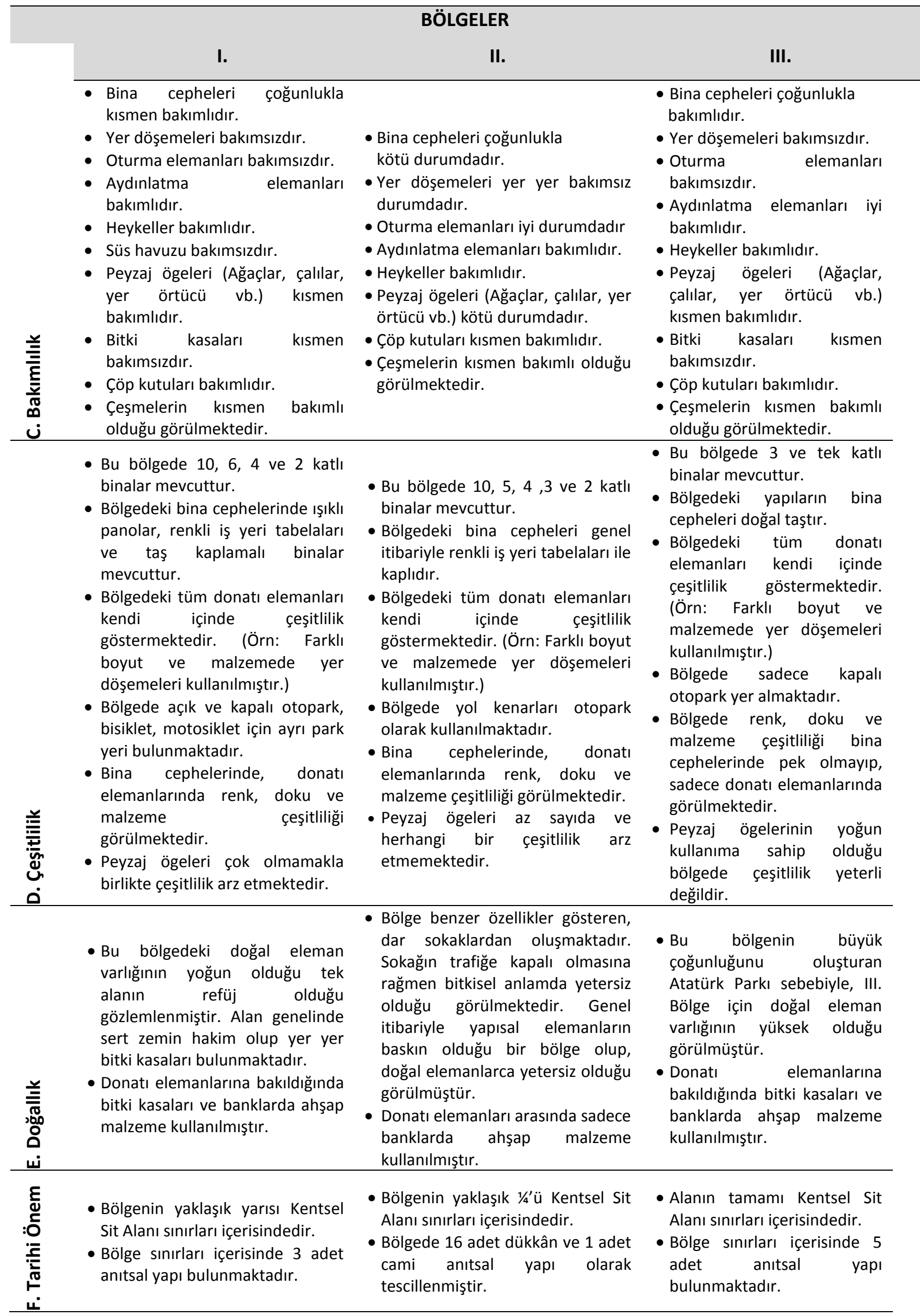


Şekil 8'de üç bölgeye ait farklı donatı elemanlarından örnekler verilmiştir.

\section{BÖLGELER}

I.
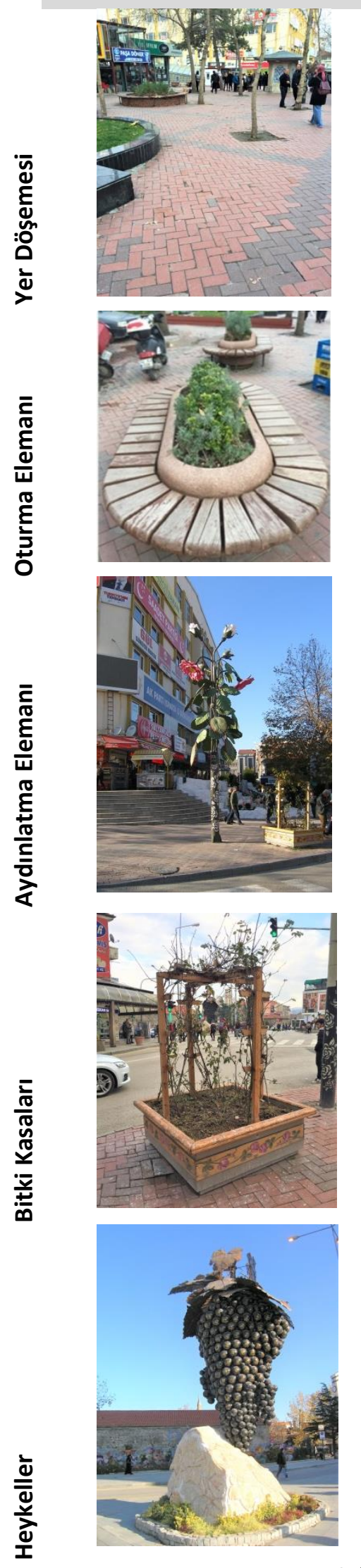

II.
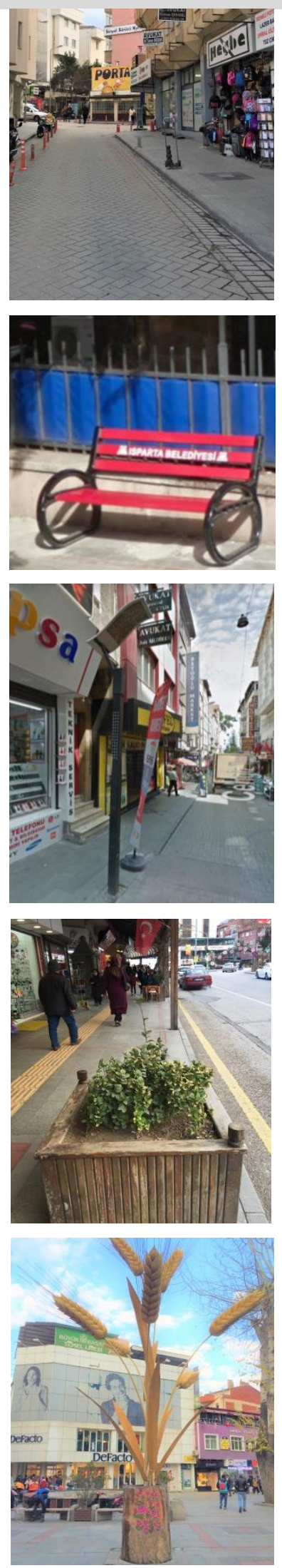

III.
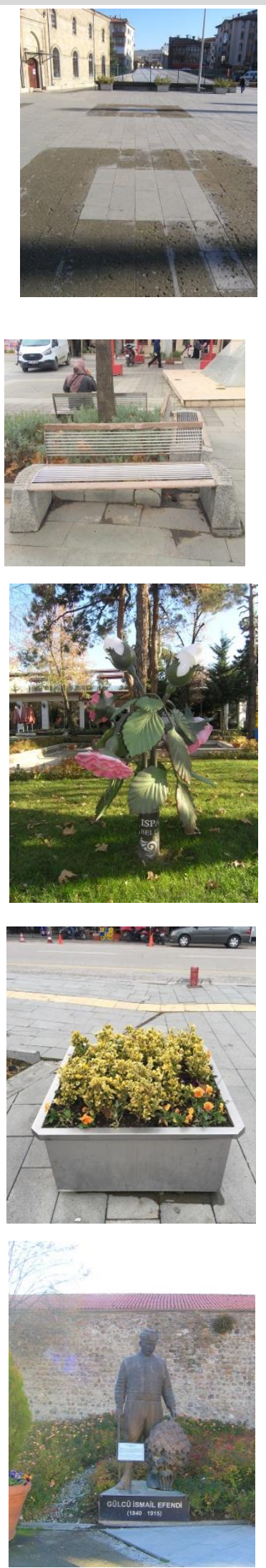

Şekil 8. Bölgelerden donatı elemanı örnekleri 
Bölgesel değerlendirme formu -2 ve +2 (-2: çok kötü, -1 : kötü, 0: orta, 1: iyi, 2: çok iyi) arasında puanlar verilerek oluşturulmuştur. Üç bölgenin puanları toplanarak Isparta kent merkezinin toplam görsel estetik değeri hesaplanmıştır. Çizelge 4 'de değerlendirme bulguları yer almaktadır.

Çizelge 4. Bölgesel değerlendirme bulguları

\begin{tabular}{|c|c|c|c|c|c|}
\hline \multicolumn{2}{|r|}{ Bölgesel Değerlendirme Formu } & \multicolumn{3}{|c|}{ Bölgeler } & \multirow{2}{*}{$\begin{array}{l}\text { Toplam } \\
\text { Puan }\end{array}$} \\
\hline Kriterler & & I. & II. & III. & \\
\hline \multirow{7}{*}{ 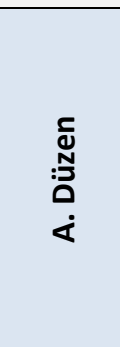 } & Bina yüksekliklerinin uyumu & -1 & 1 & 1 & 1 \\
\hline & Bina cephelerinin benzer hizada olması & -1 & 1 & -2 & -2 \\
\hline & Donatı elemanlarının birbirleriyle uyumu & -2 & -1 & -1 & -4 \\
\hline & Peyzaj ögelerinin uyumu (Ağaçlar, çalılar, yer örtücü vb.) & 0 & 0 & 1 & 1 \\
\hline & $\begin{array}{l}\text { Bina cephesindeki detaylar ve eklemelerin insan ölçeğinde } \\
\text { olması }\end{array}$ & -1 & -1 & 1 & -1 \\
\hline & Donatı elemanlarının insan ölçeğinde olması & -1 & -1 & 1 & -1 \\
\hline & Sokak genişliğinin insan ölçeğinde (düşük) olması & -2 & 1 & 0 & -1 \\
\hline \multirow{5}{*}{ 峷 } & $\begin{array}{l}\text { Sokağın iki tarafını kuşatan binaların } 4 \text { kattan fazla } \\
\text { olmaması }\end{array}$ & -1 & 0 & 1 & 0 \\
\hline & $\begin{array}{l}\text { Kapalılık oranı (Bina yüksekliğinin sokak genişliğine olan } \\
\text { oranı) }\end{array}$ & 1 & -2 & 1 & 0 \\
\hline & Bina cephelerindeki ritim, tekrar ve benzerlik & -1 & -2 & 2 & -1 \\
\hline & Peyzaj ögelerinin yoğunluğu & -1 & -2 & 1 & -2 \\
\hline & Donatı elemanlarının yoğunluğu & -2 & -1 & 1 & -2 \\
\hline \multirow{8}{*}{$\begin{array}{l}\text { 兰 } \\
\text { ह } \\
\text { 音 } \\
0 \\
\dot{0}\end{array}$} & Bina cepheleri & -2 & -2 & 0 & -4 \\
\hline & Yer döşemeleri & -2 & -1 & -1 & -4 \\
\hline & Oturma elemanları & -1 & -1 & 1 & -1 \\
\hline & Aydınlatma elemanları & 1 & 0 & 1 & 2 \\
\hline & Heykeller & 0 & 1 & 0 & 1 \\
\hline & Peyzaj ögeleri (Ağaçlar, çalılar, yer örtücü vb.) & 0 & 0 & 0 & 0 \\
\hline & Çöp kutuları & 0 & -1 & 1 & 0 \\
\hline & Çeşmeler & 1 & 1 & 1 & 3 \\
\hline \multirow{6}{*}{ 旁 } & Farkı yükseklikteki binalar & 1 & 0 & 0 & 1 \\
\hline & Farklı cephe düzenlemeleri & -1 & -2 & 0 & -3 \\
\hline & $\begin{array}{l}\text { Donatı elemanları (Çeşmeler, aydınlatma elemanı, } \\
\text { Oturma elemanları, heykeller, yer döşemeleri vb.) }\end{array}$ & 2 & 1 & 1 & 4 \\
\hline & Otopark (Kapalı otopark, Bisiklet, Motosiklet park yeri) & 1 & -1 & 0 & 0 \\
\hline & Renk, doku ve malzeme çeşitliliği & 1 & 1 & 0 & 2 \\
\hline & Peyzaj ögeleri (Ağaçlar, çalılar, yer örtücü vb.) & 0 & -1 & 2 & 1 \\
\hline \multirow{2}{*}{ 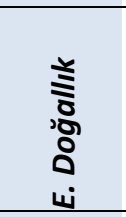 } & Doğal eleman varlığının yoğunluğu & 0 & -2 & 2 & 0 \\
\hline & Donatı elemanlarındaki doğal malzeme kullanımı & 1 & 1 & 1 & 3 \\
\hline \multirow{3}{*}{ 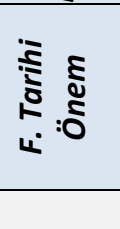 } & Kentsel Sit Alan varlığı & 0 & -1 & 2 & 1 \\
\hline & Anıtsal yapı varlığı & 1 & 0 & 2 & 3 \\
\hline & Toplam & -9 & -14 & 20 & -3 \\
\hline
\end{tabular}

Bölgesel değerlendirme form bulguları, mekânsal algı aralık çizelgesi doğrultusunda irdelendiğinde oluşan sonuçlar Çizelge 5'te verilmiştir. Yapılan çalışmalar sonucunda I. Bölge -9 puan ile orta, II. Bölge -14 puanla kötü, III. Bölge ise 20 puanla iyi bir estetik değere sahip olduğu tespit edilmiştir. Çalışma alanının bütününe bakıldığında ise üç bölgenin toplamda -3 puan ile kötüye yakın, orta düzeyde bir mekânsal estetiğe sahip olduğu sonucuna varılmıştır. 
Çizelge 5 Çalışma bölgelerine ait bulguların analiz sonuçları

\begin{tabular}{|c|c|c|c|c|c|}
\hline \multicolumn{2}{|c|}{ Bölgesel Değerlendirme Formu } & \multicolumn{3}{|c|}{ Bölgeler } & \multirow{2}{*}{$\begin{array}{c}\text { Isparta kent } \\
\text { merkezi }\end{array}$} \\
\hline Kriterler & Değerlendirme ölçütü & I. & II. & III. & \\
\hline \multirow{5}{*}{ 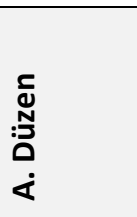 } & Çok Kötü & & \multirow{5}{*}{$x$} & \multirow{5}{*}{$x$} & \\
\hline & Kötü & $\mathrm{x}$ & & & \\
\hline & Orta & & & & \\
\hline & İyi & & & & \\
\hline & Çok İyi & & & & \\
\hline \multirow{5}{*}{$\begin{array}{l}\frac{\text { 亲 }}{\overline{\mathrm{z}}} \\
\dot{\infty} \\
\dot{\infty}\end{array}$} & Çok Kötü & & & \multirow{5}{*}{$x$} & \\
\hline & Kötü & $\mathrm{x}$ & $\mathrm{x}$ & & \\
\hline & Orta & & & & \\
\hline & İyi & & & & \\
\hline & Çok Iyi & & & & \\
\hline \multirow{5}{*}{ 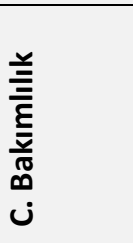 } & Çok Kötü & \multirow{5}{*}{$\mathrm{x}$} & \multirow{5}{*}{$x$} & \multirow{5}{*}{$x$} & \\
\hline & Kötü & & & & \\
\hline & Orta & & & & \\
\hline & İyi & & & & \\
\hline & Çok İyi & & & & \\
\hline \multirow{5}{*}{ 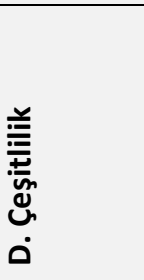 } & Çok Kötü & & \multirow{5}{*}{$x$} & \multirow{5}{*}{$x$} & \\
\hline & Kötü & & & & \\
\hline & Orta & & & & \\
\hline & İyi & $x$ & & & \\
\hline & Çok İyi & & & & \\
\hline \multirow{5}{*}{ 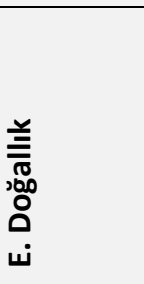 } & Çok Kötü & & \multirow{5}{*}{$x$} & & \\
\hline & Kötü & & & & \\
\hline & Orta & & & & \\
\hline & İyi & $x$ & & & \\
\hline & Çok İyi & & & $x$ & \\
\hline \multirow{5}{*}{ 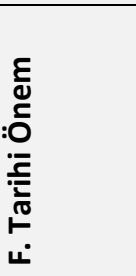 } & Çok Kötü & & \multirow{5}{*}{$x$} & & \\
\hline & Kötü & & & & \\
\hline & Orta & & & & \\
\hline & İyi & $x$ & & & \\
\hline & Çok İyi & & & $\mathrm{x}$ & \\
\hline
\end{tabular}

\subsection{Tartışma}

Çalışma sonuçlarını destekleyen farklı araştırmalar ile sonuçlar örtüşmektedir. Örneğin Çelik, 2019'un yaptığı çalışmada; Isparta tarihi kent merkezindeki, kentsel kimliğin sürdürülebilmesi açısından kentsel koruma politikaları irdelenmiştir. Araştırmaya göre kent merkezi bütününde tescilleme çalışmalarının yapılmış olmasına rağmen tarihi dokunun büyük ölçüde kaybedildiği, alandaki kültür varıklarının özgün niteliklerini çevrelerindeki uyumsuz yapılar nedeniyle yitirme tehlikesiyle karşı karşıya kaldığı, kent merkezi ve yakın çevresinde inşa edilmiş olan yeni yapıların neredeyse tümünün tarihi kentsel dokunun kimliğine aykırı yapılar olduğu sonucuna varılmıştır. Bir diğer çalışmada ise Yıldızhan, 2018'de Isparta kent merkezindeki Kaymakkapı Meydanı bazında kentlerde oluşmuş meydanların oluşum süreçlerini, şekillerini, işlevlerini, kullanım amaçlarını, fonksiyonlarını, sınıflandırılmaları ile kullanıcıların tercihlerine göre tasarımlarını incelemiş ve bulguları örneklem alanda değerlendirmiştir. Bu bağlamda, Isparta Kaymakkapı Meydanı'nın yakın çevresinin kentsel odaklar ile bütünleşme sağlayamadığı, kentin ana meydanının kimliği ile örtüşen özellikleri yerine getiremediği, yapısal ve bitkisel peyzaj ögelerinin yetersiz olduğu ve kentsel karakterinin uygun olmadığı sonucuna ulaşmıştır. Bu kapsamda, kent meydanı ve dolayısıyla kentin yaşamının sürdürebilir kılınması amacıyla kentsel tasarımına dair önermede bulunmuştur. Yapılan çalışmalar 
farklı disiplinlerden olsa da aranan hep kent yararına yapılabilecek, kente değer katabilecek, kente özgü doğru seçimlere ulaşılabilecek durumların gün yüzüne çıkması adınadır. Bu ölçüde sonuçlar ortak paydada buluşmaktadır. Kentsel mekânlar, insan-çevre ilişkisi açısından büyük öneme sahip yaşam alanları olması sebebiyle yapılaşma süreçleri ve sonrasındaki her düzenleme, her durum kullanıcılarının yaşam kalitesini etkilemektedir. Bu nedenle kentsel mekânlar için atılan her adım değerli bir sürdürülebilirlik içermelidir.

\section{Sonuç ve Öneriler}

Isparta kent merkezi mekânsal algı değerlendirmesi ile kentsel estetik potansiyelinin tespitini peyzaj mimarlığı disiplini açısından konu alan bu çalışmanın analiz bulguları yorumlandığında, kentin orta düzey estetikliğe sahip olduğu sonucuna varılmıştır. Isparta kent merkezinin mevcut mekân organizasyonu, kentin tarihi kent merkezi imajını yeterince yansıtacak, estetik potansiyelini ortaya çıkartacak nitelikler taşımamaktadır. Mekânsal algı değerlendirme parametreleri ayrı ayrı ele alındığında; Isparta kent merkezi, tarihi doku, çeşitlilik ve doğallık bakımından estetik bulunmaktadır. Fakat düzensiz yüksek bir çeşitliliğe sahip olması bu durumun mekânda karışıklık yaratmasına sebep olmaktadır. Bunların dışında bakımlılık ve düzen parametreleri orta düzey ile dengeli bulunmuş, açıklık bakımından dengesiz dağılım göstermesi ise kentin estetik potansiyeli açısından olumsuz olarak değerlendirilmiştir. Sürdürülebilirlik açısından kentin mevcut olanaklarını destekleyecek kaliteli çalışmalar yapılamamış olduğu görülmüştür. Bunun sebeplerinden biri; kentsel tasarım hakkında karar vericilerin interdisipliner bir çalışma düzeni gerçekleştirmediklerinin düşünülmesidir. Bir diğeri ise maddi kazanç sağlayabilecek çalışmalara daha fazla önem ve öncelik verilmesi gerekmektedir. Sonuç olarak kentsel estetiği sağlamak yetkili kurumların nitelikli çalışma yapmasıyla sağlanacak bir durum halindedir. Bağımsız ve liyakatli bir kent estetik komisyonunun kurulması ve yapılacak tüm tasarım projelerinin bu komisyonun onayından ve kritiğinden geçme zorunluluğunun mevzuatla getirilmesi gerekmektedir. Aksi takdirde kent tek tipleşmeye doğru gitmektedir. Kentleşme için yapılaşma faaliyetleri önem arz etse de modern mimari içerisinde doğal yeşil alanlar ile mevcut tarihi kültürel yapıların varlığı ve korunması her zaman kent uyumunda tercih sebebidir. Kentsel mekânlarda doğalın ve tarihin korunarak modern mimariyle harmanlanması uyumlu çeşitlilik sağlayarak kent ve kentlilerin yaşam kalitesini yükseltmekte, aynı zamanda mekânsal algıyı olumlu yönde etkilemektedir. Yapı mimarisinin estetik potansiyelinin düşük olduğu kentsel mekânlarda peyzaj mimarisi ögeleri kurtarıcı önem taşımaktadır. Örneğin görsel açıdan zengin, ağaçlarla süslü bir bahçenin varlığı veya uyum içinde düzenli ve bakımlı, çeşitli bitkiler ile düzenlenen mekânlar, yürüme yolları mekânsal algıyı bir anda artıya çekebilmektedir. Peyzaj ögeleri, doğanın ahengi, boyutsal ve biçimsel olarak hiyerarşik düzenli formu uyumu oluşturmaktadır. Uyum içerisindeki çeşitlilik mekânsal kaliteyi arttıran bir özelliktir. Bu bağlamda önemlidir. Tarihi çevreleri koruma ve yenileme amacıyla yapılan, plan ve projeler sürdürülebilirlik temeli üzerine kurulmuştur. Rekreasyon, ekoloji, kimlik konularını kapsamak, kentsel yaşam kalitesini artırarak daha yaşanabilir mekânları oluşturmak hedeflenmiştir (Çelik, 2004).

Günümüzde geleneksel planlama anlayışında her disiplinin kendi ilgi, sorumluluk alanında çalışması, parçacı, geçici çözümler üretmesine neden olmaktadır. Parçacı çözüm önerileri, ülkemizin farklı özelliklere, iklim koşullarına, ekonomik yapıya ve sosyal dokuya sahip bulunan yerleşimlerinde, yapı ile çevreyi bütünleştiremeyen uygulamaları ortaya çıkarmaktadır. Oysa karmaşık yapıya sahip, farkı boyutlarda bulunan fiziksel çevrelerin planlanması sürecinde tüm sorunlara tek bir disiplinin çözüm üretebilmesi mümkün değildir. Ülkemizde yaygın olarak uygulanan plan kademelenmesi incelendiğinde, nazım ve uygulama imar planlarının kent ve bölge plancısı tarafından hazırlanmakta olduğu görülmektedir. Plancının bireysel ürettiği plan kararları; mimarların yapılar, peyzaj mimarların yapılar dışında kalan açık alanları tasarlamasıyla hayata geçirilmektedir. Birbirinden bağımsız geliştirilen planlar ve tasarımlar, zaman içinde, kendileri birer sorun kaynağı haline gelebilmektedir. Disiplinler arası işbirliklerinin sağlanamaması ve yapıya çevreden yaklaşan çözümler üretilememesi; yerleşimlerin kimliğine özgü tasarımları engellemekte, kimliksiz, birbirini tekrar eden, basmakalıp fiziksel çevreleri yaratmaktadır. Geleneksel planlama sürecinde yaşanan bu sorunların tarihi çevreler için hazırlanan koruma imar planları ve kentsel tasarım projelerinde de yaşanmaması mümkün 
değildir. Disiplinler arası birlikteliğin temelinde sorunlara bütüncül bir yaklaşımla çözümler üretmek fikri yatmaktadır (Ergüleç 1999).

Bu nedenle disiplinler arası işbirliğine dayalı koruma plan ve projelerinin hazırlanması ve yönetimi için, bu disiplinlerin birlikte çalışmasını, ortak davranmasını, yetki ve sorumluluk sınırlarının tanımlanmasını sağlayacak yasa ve yönetmeliklerin hazırlanması gerekmektedir. Meslek odaları da bu işbirliğini destekleyecek biçimde yeniden yapılanmalıdır (Çelik, 2004). Kentsel çevreler için yapılması gereken, kentsel yaşam alanlarını hep bir üst düzeye taşımak ve var olan değerleri korumaktır. Çalışma sonuçları doğrultusunda Isparta kent merkezi için öneriler bölgelere göre ayrı ayrı verilmiştir.

\section{Bölge Önerileri}

- Alandaki uyumsuz çeşitlilik giderilmelidir. Bu ölçüde alandaki uyumsuz oturma grupları kaldırılarak alan ile uyumlu oturma elemanları getirilmeli ve oturma alanları için farklı mekânlar oluşturulmalıdır.

- Alana konumlandırıması gereken yeni oturma elemanları yere sabitlenmeli ve kullanıcılar ya da gerekli durumlar dışında yerleri değiştirilmemelidir. Alandaki iş hanı civarındaki yer döşemesi yenilenmeli ve alan geneli ile uyumlu bir malzeme seçimi yapılmalıdır.

- Ağaç altlarının çevresi düzenlenmeli bu bağlamda gerek mazgal veya dekoratif taşlar kullanılarak, gerekse bitki dikilerek estetik hale getirilmelidir. Kökleri görünür hale gelmiş ağaçlara ise çerçeve şeklinde yükselti yapılıp toprak ile kök görünümü iyileştirilmelidir. Bakımlı ve temiz bir görüntüye ulaşması sağlanmalıdır.

- Alan ile uyumsuz heykeller kaldırılmalı, gerekirse kentin farklı yerlerinde konumlandırılmalıdır. Yeni bir düzenleme yapılıp, vurgu yapılmak istenirse de kullanılacak objelerin Isparta'yı yansıtan ve tarihi doku ile uyumlu, insan ölçeğinde, altın oran gözetilerek yapılıp alanda bütünlük içinde yerleştirilmesi gerekmektedir.

- Traverten görünümlü havuzlar kaldırılarak, yerine bitkisel peyzaj düzenlemesi getirilip alandaki yeşil dengesi arttırımalıdır.

- İçi toprak ile doldurularak bitki düzenlemesi yapılan eski havuz yıkılıp, yer seviyesinde bir bitkisel tasarım çalışması yapılmalıdır. Hatta o alanın bütünü için çalışma gerçekleştirilip, değerlendirilmeli ve iyi bir tasarımla yumuşak ve sert peyzaj dengesi sağlanmaya çalışımalıdır.

- Bitki kasaları ise materyallerine uygun bir şekilde sınıflandırılarak alanda geçiş sağlayacak şekilde konumlandırımalı ve bitki bakımları düzenli bir şekilde yapılmalıdır.

- Refüjdeki güller, imbik vb. malzemeler kaldırılarak refüjün daha net ve temiz bir görünüme kavuşmasını sağlayacak bir bitkisel tasarım yapılmalıdır. ısparta, halısı ile de tanınan bir şehir olması sebebiyle refüje halı desenini andıran, farklı formda ve renkte bitkilerin kullanıldığı bitkisel tasarım yapılabilir.

\section{Il. Bölge Önerileri}

- Bu alanın en güçlü yönlerinden bir tanesi Tarihi Üzüm Pazarı́dır. Pazarı gören bir gözlemcinin, pazarın tarihi değerini ne ölçüde algılayabileceği meçhuldür. Çünkü pazarın dış cephesinde tarihi dokuyu yansıtan ayırt edici bir özellik göze çarpmamaktadır. Bu doğrultuda alanın tarihi dokusunun güçlenebilmesi için çalışmalar yapılmalı ve pazarın yola bakan cephelerinde iyileştirmeye gidilerek öncelikle tanıtım levhaları kaldırılmalıdır. Ayrıca yola bakan cepheler tarihi dokuyu yansıtacak şekilde kaplanarak bir silüet oluşturulmalıdır. Böylece koruma altına alınan bu tarihi yapı kendini gösterebilecektir.

- Tarihi Üzüm Pazarı sokakları ise yer döşemesi değiştirilerek eski zamanları andıran bir görüntüye kavuşturulmalıdır. Hatta uygun yerlere az sayıda oturma elemanı ve dekoratif bir aydınlatma elemanı kullanılabilir. Böylece oluşan yeni silüeti ile uyumlanmış olacaktır. Tarihi Üzüm Pazarı́nın İstasyon Caddesi'ne bakan yol kenarına, taşıt trafiğine engel olmayacak şekilde araç park cepleri yapılmalıdır. Böylece sabahtan araba park eden dükkân sahipleri yerine alana ihtiyaç doğrultusunda kısa süreli gelen kullanıcıların otopark bulma sorunu giderilebilir. 
- Mimar Sinan Cami'nin yanında bulunan Başak Heykeli ve büyük havuz kaldırılarak alandaki oturma elemanlarının düzenli bir şekilde konumlanabileceği, yeşil dokuyu arttıracak bir peyzaj düzenlemesi yapılmalıdır.

- Cengiz Topal Caddesi'ndeki ve bağıı olduğu diğer sokakta bulunan baskı beton boyanarak daha temiz bir görünüme sahip olması sağlanabilir. Bu alanda bulunan sokak ve caddelerin uygun yerlerinde bitki kasaları kullanılarak yeşil alan hacmi arttırılmalıdır.

- Alanda çöp kutuları yetersizdir. Bu nedenle sayı ve niteliği arttırımalıdır.

III. Bölge Önerileri

- Bedesten yanındaki (Güneybatı) balıklar yerine halı desenli dikey bahçe yapılabilir.

- Bedesten çarşı girişlerindeki tabelalara düzenleme getirilmeli ve bedestene uygun ahşap malzemeden yapılmış tabelalar kullanılmalıdır. Böylece hem daha uyumlu hem de estetik bir görüntü sağlanacaktır.

- Atatürk Parkı ve yakın çevresindeki bakımsız yer döşemeleri yenilenmelidir.

- Saat kulesinin bulunduğu alan gözden geçirilerek bankların düzenlenmesi gerekmektedir.

- Kutlu Bey Ulu Cami'nin yanındaki alanın bitkisel ve yapısal peyzaj düzenlemesi yapılmalıdır.

- Hükümet Meydanı çocuklar tarafından paten ve bisiklet binmek için kullanılmaktadır. Bu ölçüde çocuklar için paten kaymalarını sağlayacak mekânlar yaratılmalıdır.

- Ayrıca park daha işlevsel hale getirilmeli ve kent merkezindeki en büyük açık yeşil alan olarak değerlendirilmelidir. Bu ölçüde parka oturma elemanı dışında her yaştan kullanıcıya hitap edebilecek nitelikli bir düzenleme getirilmelidir.

\section{Teşekkür ve Bilgi Notu}

Bu makale birinci yazar tarafından SDÜ FBE Peyzaj Mimarlığı Ana Bilim Dalı'nda hazırlanan "Kentsel Çevre Algısı ve Estetiği: Isparta Kent Merkezi Örneği" adlı yüksek lisans tezinden üretilmiştir. Makalede, ulusal ve uluslararası araştırma ve yayın etiğine uyulmuştur. Çalışmada Etik Kurul izni gerekmemiştir.

\section{Kaynaklar}

Akbarishahabi, L. (2017). İmgelenebilir Kentsel Mekânların Niteliklerinin Fraktal Yaklaşım İle Saptanması ve Bir Tasarım Gramerinin Geliştirilmesi. (Doktora Tezi). Gazi Üniversitesi FBE, Şehir ve Bölge Planlama Ana bilim Dalı, Ankara. Erişim adresi (07.08.2019): https://tez.yok.gov.tr/UlusalTezMerkezi/

Alexander, C., Ishikawa, S. ve Silverstein, M. (1977). A pattern language, towns, buildings, construction. (Second edition). New York: Oxford University Press Erişim adresi (18.06.2019): https://arl.human.cornell.edu/linked\%20docs/Alexander_A_Pattern_Language.pdf

Çelik, D. (2004). Kentsel Peyzaj Tasarımı Kapsamında Tarihi Çevre Yenileme Çalışmalarııın Peyzaj Mimarlı̆̆ı Açısından Araştırıması: Beypazarı Örneği (Doktora Tezi). Ankara Üniversitesi FBE, Peyzaj Mimarlığı Ana Bilim Dalı, Ankara. Erişim adresi (11.08.2019): https://tez.yok.gov.tr/UlusalTezMerkezi/

Çelik, E. (2019). Kentsel Kimliğin Sürdürülebilirliğinde Kentsel Koruma Politikalarının Rolü: Isparta Tarihi Kent Merkezi Örneği (Yüksek Lisans Tezi). SDU FBE, Şehir ve Bölge Planlama Ana Bilim Dalı, Isparta. Erişim adresi (14.08.2019): https://tez.yok.gov.tr/UlusalTezMerkezi/

Ender Altay, E., Pirselimoğlu Batman, Z. (2019). Açık ve yeşil alanların çok ölçütlü algı değerlendirmesi. Bartın Orman Fakültesi Dergisi, 21(3): 655-664. Online ISSN :1302-0943. Erişim adresi (13.10.2020): https://dergipark.org.tr/tr/download/article-file/893234 
Ergüleç, A.S. (1999). Fiziksel Çevrenin Oluşumunda Plancı-Tasarımcı Disiplinlerin Birlikte Çalışmalarına Dayalı Model Üzerine Bir Araştırma. (Doktora Tezi ). Ankara Üniversitesi FBE, Peyzaj Mimarlığı Ana Bilim Dalı, Ankara. Erişim adresi (25.02.2020): https://tez.yok.gov.tr/UlusalTezMerkezi/

Ewing, R., Handy, S., Brownson, R., Clemente, O. ve Winston, E. (2006). Identifying and measuring urban design qualities related to walkability. Journal of Physical Activity and Health, 3(1), 223240. Erişim adresi (02.09.2019): https://pdfs.semanticscholar.org/1b37/2b2b60ed13bbfa7a89c70cbaea70192d4db8.pdf?_ga=2 .208767762.1485112205.1602790899-939388424.1577666469

Gül, A. ve Bostan Ç. (2018). Kentsel tasarım çalışmalarında interdisipliner arası işbirliği. ISUEP2018 Uluslararası Kentleşme ve Çevre Sorunları Sempozyumu: Değişim/Dönüşüm/Özgünlük. Anadolu Üniversitesi, Eskişehir.

Kaplan, S. ve Kaplan, R. (1989). The experience of nature: a psychological perspective. New York: Cambridge University Press. Erişim adresi (04.03.2019): https://www.hse.ru/data/2019/03/04/1196348207/[Rachel_Kaplan,_Stephen_Kaplan]_The_E xperience_of_(b-ok.xyz).pdf

Konuk, G., Olgun, İ., Öğdül, H., Ergönül, S., Seçkin, N. P., Başlık, S.,.., Manco, T. K. (2017). Kentsel Mekânsal Standartların Geliştirilmesi, T.C. Çevre ve Şehircilik Bakanlığı. İstanbul: Incekara Matbaacılık.

Lafsozluk. (2018). Isparta ilinin Türkiye haritasındaki yeri ve konumunu gösteren harita. Erişim Adresi (16.10.2018): https://www.lafsozluk.com/2012/01/isparta-ilinin-turkiye-haritasindaki.html

Lynch, K. (1979). The Image of The City. The M.I.T. Press, Massachusetts Institute of Technology, USA. Erişim adresi (04.03.2019) :http://www.miguelangelmartinez.net/IMG/pdf/1960_Kevin_Lynch_The_Image_of_The_City _book.pdf

Maddox, J. (1990). Complicated measures of complexity. Nature, 344 (6268), 705-810. Erişim adresi (12.06.2019): https://www.nature.com/articles/344705a0

Nasar, J.L. (1992). Visual preferences in urban street scenes: a cross cultural comparison between Japan and the United States. Environmental aethetics: theory, research and applications. Cambridge University Press, New York.

Sözbilir, M. (2011). Nitel Araştırmada Veri Toplama Araçları-2. Erişim Adresi (21.11.2018): https://fenitay.files.wordpress.com/2009/02/89-nitel arac59ftc4b1rmada-veri-toplamaarac3a7larc4b1-ii-gc3b6zlem.pdf

Tekel, A., Arı, A. (2013). Kentsel Yapılı Çevrenin Oluşumunda Aktörler ve Aktörler Arası Illişkiler Üzerine Bir Değerlendirme: Mardin Artuklu Üniversitesi Örneği. Yerel Politikalar Dergisi, 153167. Erişim adresi (11.10.2020): https://dergipark.org.tr/tr/pub/yerelpolitikalar/issue/13663/165302

Tekel, A., Ceylan Kızıltaş, A. ve Afshar, S. (2018). The Impacts of Perception Criteria on Aesthetic Response to Urban Streets A Case Study in Downtown Ankara,Turkey. Gazi Üniversity Journal of Science, 31(4), 996-1005, Ankara. Erişim adresi (13.10.2020): http://dergipark.gov.tr/gujs

Türkiye Cumhuriyeti Isparta Valiliği. (2018). Isparta ili Coğrafi Bilgisi, Türkiye Cumhuriyeti Isparta Valiliği, Isparta. Erişim Adresi (16.10.2018): http://www.isparta.gov.tr/isparta

Yıldızhan, H. (2018). Kent Meydanlarının Tasarım Yönünden İrdelenmesi: Isparta Kaymakkapı Meydanı Örneği. (Yüksek Lisans Tezi ). SD, FBE, Şehir ve Bölge Planlama Ana Bilim Dalı, Isparta. Erişim adresi (11.08.2019): https://tez.yok.gov.tr/UlusalTezMerkezi/ 